\title{
Pre and Post-monsoon Seasonal Variation of some Heavy Metal Pollution in Sediments of river Gomti in the Vicinity of Lucknow City, India
}

\author{
SAMEER, CHANDRA ${ }^{1}$; SANJAY, K. GARG*1 \\ ${ }^{I}$ Department of Plant Sciences (Faculty of Applied Sciences) M.J.P. Rohilkhand University, Bareilly, 243005, \\ U.P., India \\ *Corresponding author's e-mail: gargskplantscience@gmail.com
}

\begin{abstract}
The concentration of heavy metals ( $\mathrm{Fe}, \mathrm{As}$ and $\mathrm{Cu}$ ) was examine in riverbed sediments of Gomti river, Lucknow at selected sites in pre and post monsoon season for three consecutive years (2009-11). The concentration was ranged between (As: 0.07-0.7, Fe: 7462.00-7977.00, Cu: 10.98-36.73 $\left.\mu \mathrm{g} \mathrm{g}^{-1}\right)$ in pre-monsoon and in post-monsoon metal concentration was ranged between (As: 0.05-0.07, Fe: 543.00-7797.00, Cu: 32.00-9. $23 \mu \mathrm{g} \mathrm{g}$ ${ }^{1}$ ). Whereas Geo accumulation index (I geo), contamination factor (CF), US EPA guideline also apply to determine the readily toxicity. Fe and As pollution was found from negligible to low level while $\mathrm{Cu}$ leads from low to moderate pollution. Significant correlation found between the metals in pre and post-monsoon of studied years, in case of As it was found insignificant. Conservation and management plan is also suggest for contaminated sites. CJASEM
\end{abstract}

\section{https://dx.doi.org/10.4314/jasem.v21i3.21}

Keywords: Gomti River, Heavy metals, Contamination factor, Geo-accumulation index

Pollution of heavy metals in the aquatic environment has noticed by researcher and scientists worldwide due to its abundance, persistence and environmental toxicity (Ali et al., 2016). Overload of contaminations both organic and inorganic produce huge load, which distorted water quality and adversely affected the rich biodiversity of the rivers (Gaikwade and Kamble, 2014). Sediments of the rivers are the major factor for the assessment of the pollution introduce by anthropogenic activity, in the case of heavy metals pollution river sediments played important role in both the ways as sources and sink of heavy metals. Pollutants/contaminants settled down in the sediments along with water flow and pollute/contaminate sediments for many kilo meters, therefore metal pollution of river sediments become burning issue in concern of aquatic environment of the rivers (Marathe et al., 2011). River flows through urban areas are also have pollution load due to the discharged of untreated municipal sewage and small scale industries waste which raise in concentration of heavy metals in water and sediments of river. Heavy metals have unique importance in eco-toxicology and also potentially lethal for aquatic environment (Singare et al., 2012). Heavy metals go through many changes involving process like precipitation, dissolution, sorption for their speciation which affects the bio-availability hence the metals are responsive indicators for the change in the environment (Sundaray et al., 2012). The metals which are known toxic to the aquatic life and aquatic system are Lead Cadmium, Mercury, Copper, Zinc, Iron, and Arsenic. Industrial waste like vegetable Oil, milk dairy, and other industrial and sewage waste are also dumped in the river (Araya et al., 2011).The aim of this study is to investigate and report the temporal and seasonal variation of $\mathrm{As}, \mathrm{Fe}$, and $\mathrm{Cu}$ pollution in sediments of river Gomti in vicinity of Lucknow city India with special conservation and management plan 
Table 1 Heavy metal pollution in sediment of river Gomti in Lucknow city

\begin{tabular}{|c|c|c|c|c|c|c|c|}
\hline \multirow[b]{2}{*}{ Sources } & \multicolumn{2}{|c|}{ Source category } & \multicolumn{3}{|c|}{ Pollutant Type } & \multirow[b]{2}{*}{ Matrix involved } & \multirow[b]{2}{*}{ Pollution Mechanism } \\
\hline & & Non point & As & $\mathrm{Fe}$ & $\mathrm{Cu}$ & & \\
\hline $\begin{array}{l}\text { A Natural:- } \\
\text { a) Lithogenic } \\
\text { b) Amphibious } \\
\text { c) Granites } \\
\text { d) Gneisses, Ultra- } \\
\text { e) basic rock and } \\
\text { f) Carbonate }\end{array}$ & & & $\mathrm{Y}$ & $\mathrm{Y}$ & $\mathrm{Y}$ & $\begin{array}{l}\text { River water suspended load, } \\
\text { bed sediment soil, ground } \\
\text { water }\end{array}$ & $\begin{array}{l}\text { Dissolution } \\
\text { Suspension } \\
\text { Deposition } \\
\text { Re-preparation }\end{array}$ \\
\hline $\begin{array}{l}\text { B. Anthropogenic :- } \\
1 \frac{\text { Industrial }}{\text { a). Textile }} \\
\text { b). Paper } \\
\text { c). Distillery } \\
\text { d). Miscellaneous }\end{array}$ & $\begin{array}{l}\mathrm{Y} \\
- \\
- \\
\mathrm{Y} \\
\mathrm{Y}\end{array}$ & Y & $\begin{array}{l}\mathrm{Y} \\
\mathrm{Y}\end{array}$ & $\begin{array}{l}\mathrm{Y} \\
\mathrm{Y}\end{array}$ & $\begin{array}{l}\mathrm{Y} \\
\mathrm{Y}\end{array}$ & $\begin{array}{l}\text { Soil suspended } \\
\text { load, Biomass } \\
\text { Bed sediment Soil and } \\
\text { Ground water }\end{array}$ & $\begin{array}{l}\text { Land Spreading } \\
\text { Soaking, CEC } \\
\text { Seepage, Plumes } \\
\text { Mixing, Dispersion } \\
\text { Sorpation, Seepage } \\
\text { Soaking }\end{array}$ \\
\hline $\begin{array}{l}\text { 2. Municipal:- } \\
\text { a). Sewage effluent } \\
\text { b). Sewage sludge } \\
\text { c). Garbage dump }\end{array}$ & $\begin{array}{l}\mathrm{Y} \\
\mathrm{Y} \\
\mathrm{Y}\end{array}$ & - & $\begin{array}{l}\mathrm{Y} \\
\mathrm{Y} \\
\mathrm{Y}\end{array}$ & $\begin{array}{l}\mathrm{Y} \\
\mathrm{Y} \\
\mathrm{Y}\end{array}$ & $\begin{array}{l}\mathrm{Y} \\
\mathrm{Y} \\
\mathrm{Y}\end{array}$ & - & $\begin{array}{l}\text { Suspension, } \\
\text { Seepage soaking }\end{array}$ \\
\hline $\begin{array}{l}3 \text {.Agriculture:- } \\
\text { a). Return flow }\end{array}$ & $\mathrm{Y}$ & $\mathrm{Y}$ & $\mathrm{Y}$ & $\mathrm{Y}$ & $\mathrm{Y}$ & - & $\begin{array}{l}\text { Deposition } \\
\text { Land Spreading soaking }\end{array}$ \\
\hline
\end{tabular}

$\mathbf{Y}=$ sources are available

\section{MATERIALS AND METHODS}

Sample collection: The bed sediments samples were collected from shallow water about $20 \mathrm{~m} 2$ from the bank of river at three points $(1 / 4,1 / 2,3 / 4)$ across the river width at all the 10 sites during the study period using grab sampler and kept in polythene bags.

Sample preparation: The samples were air dried for removal of water contents associated with the sediments. The dried samples were then grinded with pestle mortal, homogenized, sieved to below 100 mesh size, sealed in clean polythene bags and stored in refrigerator till the final analysis. The total metal content was determined by digesting $1.0 \mathrm{~g}$ of homogenized and powdered sediment sample from each site with a mixture of concentrated $\mathrm{HNO}_{3}$ and $\mathrm{HClO}_{4}(10 \mathrm{ml}+2 \mathrm{ml})$. The digested samples were filtered through Whatman filter No. 42 and finally volume were made $10 \mathrm{ml}$ with $0.1 \mathrm{~N}$

Sample analysis: Metal content was estimated using Varian Model Spectra AA-250 plus Atomic Absorption Spectrophotometer.
Data analysis: The data was analyzed using one way ANOVA (Analysis of Variance). The difference between treatments was considered significant at $\mathrm{p} \leq$ 0.05 .

Estimation according to contamination factor: The contamination factor and degree of contamination are used to conclude the contamination position of the sediment in the given study. Contamination factor is calculated according to (Tomlinson et al., 1980).

Geo-accumulation index: The evaluation of sediments contamination with heavy metals using index of accumulation, Igeo which permits assessment the extent of sediments contamination with respect to global standard.

Igeo calculated by method of Muller (1979) using the following mathematical relation.

$$
\text { Igeo }=\log 2 \mathrm{Cn} /(1.5 \mathrm{Bn})
$$

Where $\mathrm{Cn}$ is the concentration of the examined metals in the sediment, $\mathrm{Bn}$ is the geochemical 
background value of a given metal and 1.5 is the background matrix correction factor.

$<0$ practically unpolluted

$0-1$ Unpolluted to moderately pollute

$1-2$ Moderately polluted

$2-3$ Moderately to strongly polluted

3 -4 Strongly polluted

$4-5$ Strong to very strongly pollute

$>5$ Very strongly polluted

$\mathrm{C}$ Background value $=$ background value

\section{RESULT AND DISCUSSION:}

Table 2 Content of heavy metals $\left(\mu \mathrm{g} \mathrm{g}^{-1}\right)$ in sediment of Gomti

river sediments in the vicinity of Lucknow city during pre-monsoon season 2009

\begin{tabular}{cccc}
\hline Sampling Sites & Arsenic & Iron & Copper \\
\hline Sitapur over bridge (Inlet) & $0.593 \pm 0.02$ & $6300.00 \pm 126.0$ & $10.98 \pm 0.21$ \\
Kudiaghat & $0.643 \pm 0.03$ & $6425.00 \pm 54.25$ & $20.23 \pm 1.02$ \\
Hanuman setu & $0.675 \pm 0.05$ & $6503.00 \pm 96.09$ & $25.85 \pm 1.29^{\mathrm{a}}$ \\
Laxmanmela park & $0.722 \pm 0.01^{\mathrm{a}}$ & $5563.00 \pm 78.56$ & $23.63 \pm 0.47$ \\
Saheed park & $0.611 \pm 0.02$ & $5401.00 \pm 89.54$ & $23.12 \pm 0.69$ \\
Dilkhusha railway over bridge & $0.523 \pm 0.01$ & $7462.00 \pm 44.95^{\mathrm{a}}$ & $21.53 \pm 0.43$ \\
\hline
\end{tabular}

Values shown are the mean \pm S.D. of 6 samples. $a=$ significant value

Table 3 Content of heavy metals $\left(\mu \mathrm{g} \mathrm{g}^{-1}\right)$ in sediment of Gomti river sediments in the vicinity of Lucknow city during post-monsoon season 2009

\begin{tabular}{cccc}
\hline Sampling Sites & Arsenic & Iron & Copper \\
\hline Sitapur over bridge (Inlet) & $0.632 \pm 0.032$ & $5300.00 \pm 116.0$ & $10.54 \pm 0.31$ \\
Kudiaghat & $0.651 \pm 0.014$ & $5332.00 \pm 229.8$ & $15.21 \pm 0.95$ \\
Hanuman setu & $0.532 \pm 0.024$ & $5431.00 \pm 104.6$ & $29.03 \pm 0.87^{\mathrm{a}}$ \\
Laxmanmela park & $0.522 \pm 0.020$ & $5264.00 \pm 107.4$ & $21.31 \pm 0.53$ \\
Saheed park & $0.531 \pm 0.010$ & $5093.00 \pm 101.8$ & $19.05 \pm 0.49$ \\
Dilkhusha railway over bridge & $0.653 \pm 0.026^{\mathrm{a}}$ & $5384.00 \pm 203.2^{\mathrm{a}}$ & $20.43 \pm 0.61$ \\
\hline
\end{tabular}

Values shown are the mean \pm S.D. of 6 samples, $a=$ significant value

Table 4 Content of heavy metals $\left(\mu \mathrm{g} \mathrm{g}^{-1}\right)$ in sediment of Gomti river sediments in the vicinity of Lucknow city during pre-monsoon season 2010

\begin{tabular}{cccc}
\hline Sampling Sites & Arsenic & Iron & Copper \\
\hline Sitapur over bridge (Inlet) & $0.523 \pm 0.008$ & $6485.00 \pm 97.06$ & $12.73 \pm 0.04$ \\
Kudiaghat & $0.722 \pm 0.067^{\mathrm{a}}$ & $7795.00 \pm 54.89$ & $14.54 \pm 0.06$ \\
Hanuman setu & $0.713 \pm 0.081$ & $6925.00 \pm 74.56$ & $36.73 \pm 2.74^{\mathrm{a}}$ \\
Laxmanmela park & $0.7250 \pm 0.071$ & $5758.00 \pm 43.97$ & $25.84 \pm 1.43$ \\
Saheed park & $0.744 \pm 0.053$ & $5975.00 \pm 98.32$ & $25.872 \pm 1.94$ \\
Dilkhusha railway over bridge & $0.793 \pm 0.029$ & $7957.00 \pm 80.21^{\mathrm{a}}$ & $29.93 \pm 2.59$ \\
\hline
\end{tabular}

Values shown are the mean \pm S.D. of 6 samples, $a=$ significant value 
Table 5 Content of heavy metals $\left(\mu \mathrm{g} \mathrm{g}^{-1}\right)$ in sediment of Gomti

river sediments in the vicinity of Lucknow city during post-monsoon season 2010

\begin{tabular}{cccc}
\hline Sampling Sites & Arsenic & Iron & Copper \\
\hline Sitapur over bridge (Inlet) & $0.431 \pm 0.004$ & $4980.00 \pm 134.75$ & $9.73 \pm 0.03$ \\
Kudiaghat & $0.5173 \pm 0.001$ & $5125.00 \pm 21.43$ & $19.23 \pm 0.53^{\mathrm{a}}$ \\
Hanuman setu & $0.5621 \pm 0.001$ & $5362.00 \pm 37.84$ & $23.23 \pm 0.69$ \\
Laxmanmela park & $0.5438 \pm 0.01$ & $4954.00 \pm 75.96$ & $23.74 \pm 0.43$ \\
Saheed park & $0.564 \pm 0.002$ & $4834.00 \pm 86.21$ & $22.153 \pm 0.26$ \\
Dilkhusha railway over bridge & $0.487 \pm 0.002^{\mathrm{a}}$ & $6753.00 \pm 53.97^{\mathrm{a}}$ & $19.29 \pm 0.75$ \\
\hline
\end{tabular}

Values shown are the mean \pm S.D. of 6 samples, $a=$ significant value

Table 6 Content of heavy metals $\left(\mu \mathrm{g} \mathrm{g}^{-1}\right)$ in sediment of Gomti river sediments in the vicinity of Lucknow city during pre-monsoon season 2011

\begin{tabular}{cccc}
\hline Sampling Sites & Arsenic & Iron & Copper \\
\hline Sitapur over bridge (Inlet) & $0.423 \pm 0.008$ & $6485.00 \pm 97.06$ & $12.73 \pm 0.04$ \\
Kudiaghat & $0.622 \pm 0.067^{\mathrm{a}}$ & $6795.00 \pm 54.89$ & $16.54 \pm 0.06$ \\
Hanuman setu & $0.711 \pm 0.081$ & $6905.00 \pm 44.16$ & $26.73 \pm 2.74$ \\
Laxmanmela park & $0.730 \pm 0.076$ & $5761.00 \pm 43.17$ & $25.84 \pm 1.43$ \\
Saheed park & $0.763 \pm 0.053$ & $5975.00 \pm 98.32$ & $25.87 \pm 1.94$ \\
Dilkhusha railway over bridge & $0.798 \pm 0.021$ & $7977.00 \pm 89.21^{\mathrm{a}}$ & $29.93 \pm 2.59^{\mathrm{a}}$ \\
\hline
\end{tabular}

Values shown are the mean \pm S.D. of 6 samples, $a=$ significant value

Table 7 Content of heavy metals $\left(\mu \mathrm{g} \mathrm{g}^{-1}\right)$ in sediment of Gomti river sediment in the vicinity of Lucknow city during post-monsoon season 2011

\begin{tabular}{cccc}
\hline Sampling Sites & Arsenic & Iron & Copper \\
\hline Sitapur over bridge (Inlet) & & & \\
Kudiaghat & $0.501 \pm 0.003$ & $5321.23 \pm 0.014$ & $13.94 \pm 0.03$ \\
Hanuman setu & $0.540 \pm 0.001^{\mathrm{a}}$ & $5433.12 \pm 0.018$ & $14.13 \pm 0.02$ \\
Laxmanmela park & $0.509 \pm 0.01$ & $4783.21 \pm 0.011^{\mathrm{a}}$ & $28.13 \pm 3.0^{1}$ \\
Saheed park & $0.503 \pm 0.01$ & $4331.22 \pm 0.016$ & $28.56 \pm 3.04$ \\
Dilkhusha railway over bridge & $0.548 \pm 0.01$ & $4101.21 \pm 0.003$ & $29.93 \pm 3.05$ \\
\hline
\end{tabular}

Values shown are the mean \pm S.D. of 6 samples, $a=$ significant value

Content of Heavy Metals $\left(\mu g_{-} g^{-1}\right)$ In Sediment: Arsenic (As): As level in pre-monsoon season of year 2009 was ranged from $0.523-0.722 \mu \mathrm{g} \mathrm{g}-{ }^{1}$ maximum level was observed at the site Laxamanmela Park. In post-monsoon 2009 As ranged from $0.522-651 \mu \mathrm{g}$ $\mathrm{g}^{-1}$ here the maximum level was observed at the Kudiya ghat (Table 3.). In pre-monsoon 2010 As range was observed from $0.798-0.523 \mu \mathrm{g} \mathrm{g}^{-1}$ site Dilkusha rail over bridge its level was higher (Table 3 ), whereas in post monsoon its range was observed from $0.5621-0.431 \mu \mathrm{g} \mathrm{g}^{-1}$ and highest level was observed at the site Hanuman setu (Table 4). In premonsoon season 2011 the level of As was observed from $0.793-0.423 \mu \mathrm{g} \mathrm{g}^{-1}$ (Table 5) and in postmonsoon season of year 2011 it ranged from 0.548 $0.408 \mu \mathrm{g} \mathrm{g}^{-1}$. By evaluating the tables (1-6) the level of As was found higher most at site Laxamanmela park and Hanuman setu it is due to the disposal and discharge of sewage and effluent.
Iron $(\mathrm{Fe})$ : In the year 2009 pre-monsoon season the level of Fe was ranged from $549-746 \mu \mathrm{g} \mathrm{g}^{1}{ }^{1}$ and its range was found between $5263-5431 \mu \mathrm{g} \mathrm{g}^{-1}$ in post monsoon 2009. However the higher values are found at the site Dilkusha rail over bridge in pre-monsoon and Hanuman setu at post monsoon. In pre-monsoon and in post monsoon $2010 \mathrm{Fe}$ level was found 6753 $4980 \mu \mathrm{g} \mathrm{g}^{-1}$ and $4834-6753 \mu \mathrm{g} \mathrm{g}^{-1}$ however in pre and post-monsoon it the maximum level was recorded at Dilkusha rail over bridge season. In year 2011, pre-monsoon season maximum level of Fe was found at site Dilkusha rail over bridge in $7977 \mu \mathrm{g} \mathrm{g}^{-}$ ${ }^{1}$ and range was observed from $7977-5758 \mu \mathrm{g} \mathrm{g}^{-1}$ (Table 5). In post-monsoon season 2011 highest level was observed at site Kudiya ghat $5433 \mu \mathrm{g} \mathrm{g}^{-1}$. It was noted that the site Sitapur over bridge is least polluted in all the season in all the three years (Table 1-6). Singh et al., (2005) and also observed range of Fe from 5051.485 - $8291.485 \mu \mathrm{g} \mathrm{g}^{-1}$ in Gomti river sediments 
Copper $(\mathrm{Cu})$ : In case of the $\mathrm{Cu}$ in pre-monsoon period 2009, it ranged from 25.85-10.98 $\mu \mathrm{g} \mathrm{g}^{-1}$ maximum level was observed at station Hanuman setu i.e. $25.85 \mu \mathrm{g} \mathrm{g}^{-1}$ (Table 1). The level of $\mathrm{Cu}$ in post-monsoon ranged from 29.03- $10.54 \mu \mathrm{g} \mathrm{g}^{-1}$, highest value was observed at the site Hanuman setu which is situated at the midpoint of city (Table 2). In the pre-monsoon period 2010 maximum level of $\mathrm{Cu}$ was observed at the site Hanuman setu $36.73 \mu \mathrm{g}$ g. Whereas in post-monsoon 2010 season highest level was observed at the site Laxamanmela park $23.74 \mu \mathrm{g}$ $\mathrm{g}^{-1}$. While in pre-monsoon season 2011 and its level was ranged from 29.93-12.73 $\mu \mathrm{g} \mathrm{g}^{-1}$ (Table 5), maximum value of $\mathrm{Cu}$ was observed at site Dilkusha rail over bridge, whereas in post-monsoon season it was found high at site Dilkusha $32.11 \mu \mathrm{g} \mathrm{g}^{-1}$ and range was observed between $32.11 \quad 13.94 \mu \mathrm{g} \mathrm{g}^{-1}$ (Table 6). By comparing the guideline for contaminated fresh water sediments (US EPA, 1977) its concluded that site Hanuman setu, Laxaman mela park, Saheed park and Dilkusha were found moderate polluted at most of the sampling time while in term of As and Fe it was found low polluted to unpolluted.

\section{Index of Geo Accumulation:}

Table 8 Geo accumulation index of Gomti river in vicinity of Lucknow city pre and post monsoon of 2009, 2010 and 2011

\begin{tabular}{cccc}
\hline Sampling Sites & Arsenic & Iron & Copper \\
\hline Sitapur over bridge & 0 & 0 & 0 \\
Kudiyaaghat & 0 & 0 & 0 \\
Hanuman setu & 0 & 0 & 0 \\
Laxamanmela park & 0 & 0 & 0 \\
Saheed Park & 0 & 0 & 0 \\
Dilkusharailover bridge & 0 & 0 & 0 \\
\hline
\end{tabular}

Index of geo accumulation (Igeo) calculated for all the heavy metals ( $\mathrm{As}, \mathrm{Fe}, \mathrm{Cu}$,) given in table. The geo accumulation index consists of seven grade ranged from unpolluted to highly polluted. Class 6 indicates that 64 fold enrichment above the back ground value. The Igeo class for Gomti river sediments varies metal to metal and place to place $\mathrm{As}, \mathrm{Fe}$, and $\mathrm{Cu}$. Based on the geo accumulation indices, the Gomti river sediments from Sitapur over bridge to Dilkusha rail over bridge considered to be unpolluted with respect to $\mathrm{As}, \mathrm{Fe}$, and $\mathrm{Cu}$ during the studied period 2009, 2010 and 2011 pre and post monsoon at the given sites (Table 7).

By categorizing Gomti river sediments from Sitapur over bridge to Dilkusha rail over bridge according to geo accumulation index the studied sediments are considered to be unpolluted with respect to As, Fe, and $\mathrm{Cu}$ all over the studied time 2009, 2010 and 2011 pre and post monsoon at the given sites. Singh et al., (2005) and Gaur et. al, (2005) also resulted in their study that the Gomti river sediments are in unpolluted from the $\mathrm{Fe}, \mathrm{Cu}, \mathrm{Cd}, \mathrm{Mn}$ were in case of other metal $\mathrm{Pb}$ its recorded partially to moderate polluted.

Contamination Factor $(C F)$ :
Table 9 Description of the contamination factor

\begin{tabular}{cc}
\hline Contamination factor & Description \\
\hline $\mathbf{C F}<\mathbf{1}$ & Low level of contamination \\
$\mathbf{1} \leq \mathbf{3}$ & Moderate level of contamination \\
$\mathbf{3} \leq \mathbf{6}$ & Considerable level of contamination \\
$\mathbf{6} \leq \mathbf{C F}$ & Very high level of contamination \\
\hline
\end{tabular}

The CF value of As was ranged from $0.04-0.06$ (Table 8) and the highest CF value was recorded at the site Dilkusha rail over bridge (outlet of river from city) in pre- monsoon season. In the case of Fe the $\mathrm{CF}$ as noted from $0.10-0.17$ in studied year 2009 to 2011 the lowest value was recorded in the year 2009 in post monsoon season at Saheed Park were as the highest value was recorded at Dilkusha rail over bridge in pr-monsoon season. The $\mathrm{CF}$ value of $\mathrm{Cu}$ was ranged from $0.24-0.81$ the lowest value was recorded at the site Sitapur over bridge in pre monsoon season were as the highest value was noted at the site Hanuman setu. The $\mathrm{CF}$ value of $\mathrm{Cu}$ at site Hanuman setu in 2010 post-monsoon season was recorded 0.81 nearby 1 . Sediments of river Gomti in Lucknow is found to low level of contamination but rising towards moderate level of contamination and according to the Pollution load Index the load of studied pollutant was founded low at the in inlet of the city while it was found to rising staidly as the river flow out of the city. It is also concluded from the study that the average concentration of the metals 
in sediments of river Gomti at studied site are found rising continuously year by year season by season.

\section{Correlation Coefficient:}

Table 10 Correlation in heavy metal concentration pre and post monsoon 2009, 2010 and 2011

\begin{tabular}{llll}
\hline & As & Fe & Cu \\
\hline $\begin{array}{l}\text { Arsenic (As) } \\
\text { Iron (Fe) }\end{array}$ & -0.246 & & \\
Copper (Cu) & & 0.126 & \\
\hline
\end{tabular}

Correlation among the studied heavy metals of Gomti river sediments as given in Table 9 revealed significant relation between the concentration of metals in pre and post- monsoon of 2009, 2010 and 2011 in case of $\mathrm{Cu}(0.75)$ and $\mathrm{Fe}(0.12)$, were as in case of As it was found insignificant (-0.24) it prove that except As the nature and source of pollutants in both the season and in all the analysis years (2009, 2010 and 2011)found same, This nature of relation among the pollutants justified that the metal concentration in sediments of river Gomti in vicinity of Lucknow city is mostly influenced by the disposal and discharge of the un treated waste water because except As the other studied metals (Fe, and $\mathrm{Cu}$ ) are found usually in the house hold and industrial waste.

Conclusion: In pre monsoon season concentration of metals are observed more than post monsoon, $\mathrm{Cu}$ leads to low polluted to moderate pollute according to the guide line of US EPA (1977), whereas Fe and As leads to no polluted to high polluted, Geo accumulation Index state that the quality of bed sediments of Gomti river is low polluted but in turns to moderate polluted readily the same consequence also discovered by estimating the Contamination factor and Pollution load.

Managemant plan for restoration of Gomti river sediments at Lucknow city India

The recognition of major risks and satisfactory management of sediment pollution with removal/deleting of pollutants is essential for the development of river ecosystem and human health (Todorova et al,2015).The primarily sources of heavy metals in a river system is naturals sources like weathering of soil and rocks and the other major source is anthropogenic/human activity anthropogenic/human activity is mainly responsible for the over load of pollution in river Gomti within vicinity of Lucknow city ( Srivastav et al.,2011). Khera and Khera (2012) reported that the waste water sample collected from the adjacent of industrial area and reticently locality was found unfit for direct disposal in river. Suggestions for the protection of river from pollution (1) Using alternative method for sewage disposal like dry sanitation, sanitation involve less or no water for disposal (2) Properly maintenance of sewage and drainage system, and STP (3) Uses of latest technologies for recycling of waste instated of disposal (4) There should be arrangement of proper sewerage system on the river side (both the banks) for the appropriate collection and treatment of sewage, modified drainage system and land use changes can reduce pollution load on Gomti river in Lucknow city (5) Prohibited inappropriate garbage dumping on the river side (6) Arrangements of public laboratory for the prevention of open defecation (7) At the banks of river vegetation should grow to improve the quality of water and sediments.

\section{REFERENCES}

Ali ,M M; Ali , M L; Islam, M I; Rahman, M Z (2016). Preliminary assessment of heavy metals in water and sediment of Karnaphuli River, Banglades. Envi.Nano tech.Monit. and Managrment.5.27-75

Arya, S K; Singh, A; Mathur, A and. Rupainwar, D C (2011). Heavy metal pollution in river Gomti at Lucknow city.Poll Res. 30 (1): 61-65.

Fritioff, A and Geger, M (2007).Fate of cadmium in elodea canadensis.Chemosphere. 67.365-375.

Gaikwad, SS and Kamble, N A (2014). Heavy metal pollution of indian river and its biomagnifications In the mollusks.Oct. Jour. Env. Res. 2(1): 67-76

Gaur, K V; Gupta, S K; Pandey, S D; Mishra, K G (2005).Distribution Of Heavy metals in Sediment and water of River Gomti. Environmental Monitoring and Assessment, 102: 419-433.

Khare, R and Khare, R (2012).Analytical study of Gomti river water. IOSR Journal of Applied Chem. 2(4):37-40.

Muller, M and Martin, M J (1979). Elemental mass balance of materials carried by major world rivers. Marine Chemistry. 7 (3): 73-106

Marathe, R B; Marathe, Y V; Sawant, C P; Srivastava, S S (2011). Detection of trace 
elementsin surface and sediments of Tapti river: A case study. Archive of applied science resh . 3(2):472-476.

Singare, P U; Ravindra, M; Mishra, M and Trivedi, P (2012). Heavy Metal Pollution in Mithi River of Mumbai. Frontiers in Science. 2(3): 28-36.

Singh, P K; Malik, A; Sinha, S; Singh, V K, and Murthy R C (2005). Estimation of Source of Heavy Metal Contamination In Sediments of Gomti River (India) using Principal Component analysis. Water, Air, and Soil Pollution. 166: 321-341,

Srivastav, S; Srivastava, A; Negi, M P S; and Tandon, K (2011).Evaluation of effect of drains on water quality of river Gomti in Lucknowcity using multivariate statistical techniques. IJES. 2(1):1-7.

Srivastava, A and Srivastava, S (2012).Assessment of physico-chemical properties and sewage pollution indicator bacteria in surface water of river Gomti in Uttar Pradesh. IJES. 2 (1): 335336.

Sundaray, S K; Nayak, B B; Kanungo T K; Kanungo, D (2012).Dynamics and quantification of dissolved heavy metals in the Mahanadi river estuarine system, India. Environ Monit Assess.,184. 1157-1179.

Todorova, Y; Yotinov, I; Lincheva, S and Topalova, Y (2015). A Large-Scale Identification of Sediment Associated Risks of Contamination with Heavy Metals and Organics: Indicators and Algorithms. Journal of Water Resource and Protection. 7:101-110.

Thomilso, D C; Wilson, D J; Hariss, C R and Jeffery, D (1980). Problem in heavy metals in estuaries and the formation of pollution index. Helgol.Wiss.Meere-sunlter. 33(14): 566-575.

USEPA, (1997).www.epa.gov. 